DOI: $10.17516 / 1997-1397-2021-14-6-726-734$

УДК 532.542

\title{
Simulation of Thermoplastic Powder Cold Spraying
}

\author{
Tatyana A. Brusentseva* \\ Vladislav S. Shikalov ${ }^{\dagger}$ \\ Sergei A. Lavruk \\ Vasily M. Fomin ${ }^{\S}$
}

Khristianovich Institute of Theoretical and Applied Mechanics SB RAS

Novosibirsk, Russian Federation

Received 10.04.2021, received in revised form 10.06.2021, accepted 20.08.2021

Abstract. The work is devoted to the deposition of composite powder materials by cold spray method. As a spraying material, a thermoplastic compound «WAY» for marking the roadway was used. An asphalt concrete was used as a substrate. As a result of experimental studies, the dependence of the deposition efficiency on the stagnation temperature of the working air in the ejector nozzle was obtained. The ANSYS Fluent package was used for evaluative modeling of the cold spraying process. Gas flow patterns were obtained in the computational domain without particles and taking into account the interaction of the flow with particles. The trajectory of the particles was calculated for various spraying parameters.

Keywords: cold spray, thermoplastic, deposition efficiency, numerical calculation, two-phase flows, ejector nozzle.

Citation: T. Brusentseva, V.Shikalov, S. Lavruk, V. Fomin, Simulation of Thermoplastic Powder Cold Spraying, J. Sib. Fed. Univ. Math. Phys., 2021, 14(6), 726-734. DOI: 10.17516/1997-1397-2021-14-6726-734.

\section{Introduction}

The phenomenon of coating formation by the cold spray method was first discovered at the ITAM SB RAS in the early 80 s of the last century. Cold spray is a new and rapidly developing coating method. Traditional gas thermal methods are related to temperature and phase changes. As the name suggests, cold spray occurs at lower temperatures, in fact below the melting point of the material. From a safety point of view, the cold spray process takes place using only inert gases (nitrogen, helium, air), and not flammable mixtures. Detailed information about the cold spray method is presented in monographs: the first in the world [1], and those published later [2-4]. Thanks to the research carried out, various technical solutions were proposed due to the optimal choice of the working gas, the size and shape of the powder particles, the spraying strategy (number of passes, scanning speed, etc.), the spraying angle, the powder heating, the optimal geometry of the masks and sublayers. We also note the work on the deposition of submicron powders in vacuum [5], the use of micro nozzles (up to $50 \mu \mathrm{m}$ in diameter) for the deposition

\footnotetext{
*brusentseva@itam.nsc.ru https://orcid.org/0000-0002-7235-9763

†v.shikalov@gmail.com https://orcid.org/0000-0002-0491-2803

†lavruks@mail.ru

§fomin@itam.nsc.ru https://orcid.org/0000-0002-2811-0143

(c) Siberian Federal University. All rights reserved
} 
of nanopowders (including non-metals) [6], on the metallization of glass and silicon [7], various plastics [8-11], as well as the spraying of plastic powders [12,13]. According to the literature, it is possible to obtain dense coatings from polymeric materials on various substrates by the lowpressure cold spray method; however, the process is accompanied by a low deposition efficiency (less than 10\%). It is known that for efficient spraying of each material, it is necessary to select individual parameters of the gas flow. Therefore, when spraying pre-prepared mixtures of powders that differ in their physicomechanical characteristics, it is extremely difficult to find the optimal parameters of the gas flow that ensure effective spraying of each component.

This work is a continuation of research $[14,15]$ and is devoted to the study of the process of formation of continuous composite polymer coatings on the surface of asphalt concrete. To achieve this goal, an approach was used that combines experimental research and numerical modeling.

\section{Materials and methods}

As a spraying material, we used a thermoplastic compound for marking the roadway «WAY» (GOST 52575-2006). The composition includes a film-forming agent (15-30\%), a plasticizer (3-10\%), titanium dioxide (4-10\%), an anti-sediment additive (3-10\%), glass microspheres (0-30\%) and a mineral filler (Fig. 1). The elemental composition of a thermoplastic obtained using an EVO MA15 electron microscope (Carl Zeiss, Germany) using a backscattered electron detector equipped with an attachment for X-ray spectral analysis (Oxford Instruments X-Max $80 \mathrm{~mm}^{2}$, United Kingdom) is shown in Tab. 1.

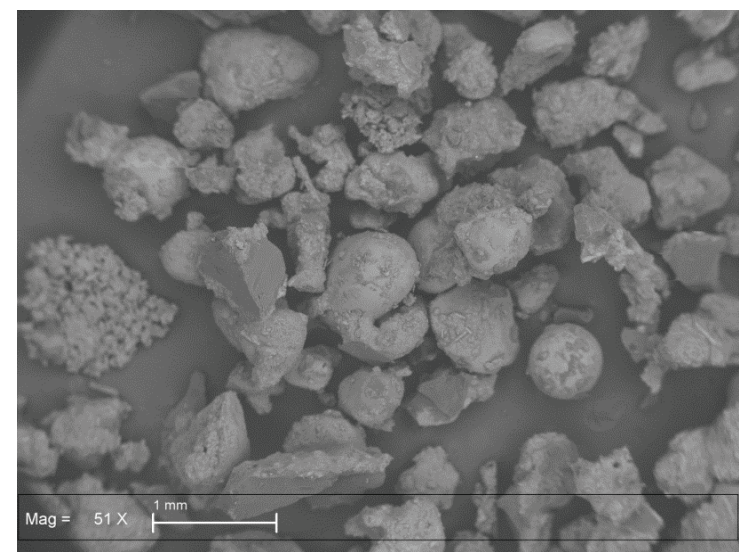

Fig. 1. Micrograph of the general view of the thermoplastic «WAY» particles

An asphalt concrete was used as a substrate. Cold spraying experiments were carried out at the cold spray facility (ITAM SB RAS) (Fig. 2), which includes a working gas heater, a drum-type powder feeder, and a prechamber-nozzle unit.

Spraying was carried out using an ejector nozzle of constant cross section with a diameter of $15 \mathrm{~mm}$ and a length of $140 \mathrm{~mm}$. The use of an ejector nozzle makes it possible to use an opentype feeder operating at atmospheric pressure for powder feeding a spraying unit. As a result, the system for feeding powder is greatly simplified, and feeding of low-flowing materials and suspensions is also improved. One of the main features of the gas flow in the ejector nozzle is the presence of ejecting and ejected flows mixture. The flow of ejected air ensures the transportation 
Table 1. Elemental composition of thermoplastic «WAY»

\begin{tabular}{|l|l|l|}
\hline Element & Wt. \% & At. \% \\
\hline $\mathrm{C}$ & 23.49 & 36.17 \\
\hline $\mathrm{O}$ & 40.37 & 46.66 \\
\hline $\mathrm{Mg}$ & 1.34 & 1.02 \\
\hline $\mathrm{Al}$ & 0.77 & 0.53 \\
\hline $\mathrm{Si}$ & 3.60 & 2.37 \\
\hline $\mathrm{Ca}$ & 19.87 & 9.17 \\
\hline $\mathrm{Ti}$ & 10.55 & 4.07 \\
\hline Итого & 100 & 100 \\
\hline
\end{tabular}

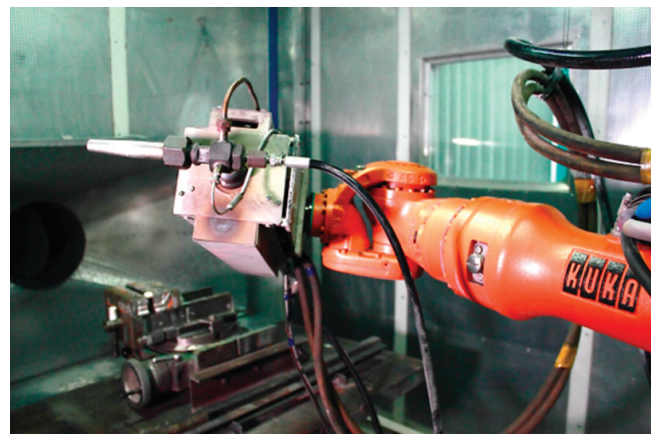

Fig. 2. Cold spray unit on industrial robot

of powder material from the feeder to the nozzle. Air was chosen as the working gas. Standoff distance was constant and equal to $30 \mathrm{~mm}$, the nozzle traverse speed was $5 \mathrm{~mm} / \mathrm{s}$. Deposition efficiency was determined as the ratio of the coating mass to the mass of the consumed powder. The sample was weighed before and after spraying; a portion of the powder, which was poured into the feeder, was also weighed.

For evaluative modeling of the process of cold spraying, the authors used the ANSYS Fluent package, which includes a module for calculating the motion of solid particles in a gas [16]. The process of air flow containing fine particles of a multicomponent thermoplastic powder through an ejector nozzle is simulated taking into account gravity. The movement of the powder was simulated in the Lagrangian approach. Fig. 3 shows the computational domain that simulates the internal space of the ejector nozzle, as well as the boundary conditions. The mesh consisted of rectangular elements, with a thickening towards the wall region. The number of grid elements at the initial stage was 50000 .

Gas enters the inlet section of Inlet 2, powder enters through Inlet 1 . The walls of the nozzle are designated as wall1, the substrate is designated as wall2. In calculations, air is a continuous, «carrier» phase, in which individual particles of another phase are present in small concentrations. The problem was solved in the Lagrangian formulation, when the dispersed phase is considered as a set of particles (material points), the motion of which is calculated according to Newton's second law, taking into account the effect of the flow with particles and the gravity forces. The calculation was carried out in two steps. On the first step the calculation of gas flow in the nozzle is made without injecting of the particles. Then on the second step some particles are injected through the Inlet 1. After injecting of the particles some changes in flow regime take place. The 


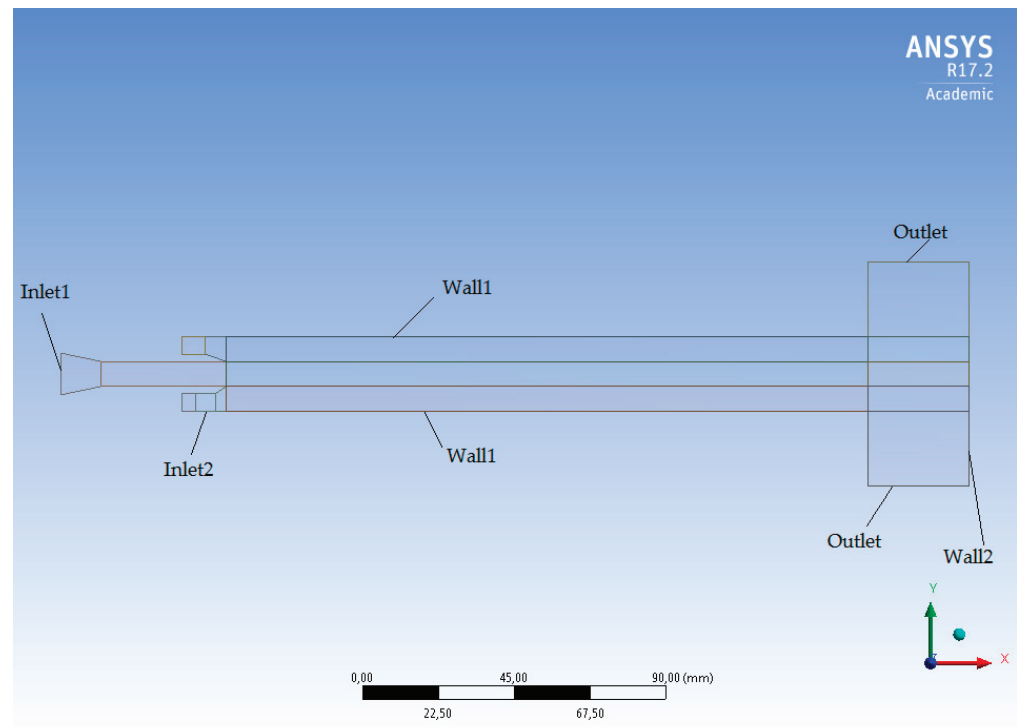

Fig. 3. Computational model of the ejector nozzle

RNG k-epsilon model was chosen as the turbulence model. For the calculation, we used the splitting scheme for the AUSM vector flux. On the walls (wall1, wall2), the no-leakage condition was set for gas dynamics calculations. For modeling the interaction of the particles with gas phase is used next boundary conditions: out of the calculation domain (escape) is set by default for inlet (inlet1, inlet2) and outlet (outlet) boundaries, absolutely elastic rebound (reflect) is set by default for walls (wall1), and snapping (trap) is also set particles to the boundary wall2.

\section{Results and discussion}

Fig. 4 shows an example of a photograph of a sample with thermoplastic coating tracks sprayed at an air stagnation temperature of 160 and $26{ }^{\circ} \mathrm{C}$.

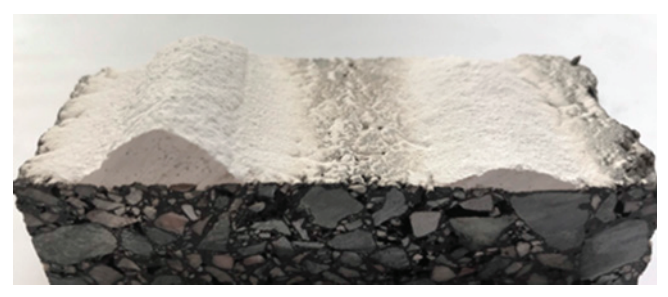

Fig. 4. Coating tracks sprayed at an air stagnation temperature of 160 (left) and $26{ }^{\circ} \mathrm{C}$ (right)

Fig. 5 shows that an increase in the gas stagnation temperature leads to an increase in the deposition efficiency. The largest value $(6 \%)$ was achieved at a stagnation pressure of $1.5 \mathrm{MPa}$ and a stagnation temperature of $200{ }^{\circ} \mathrm{C}$.

It can be assumed that the heating of polymer particles in the flow to the softening/melting temperature promotes an increase in the deposition efficiency of the coating. 


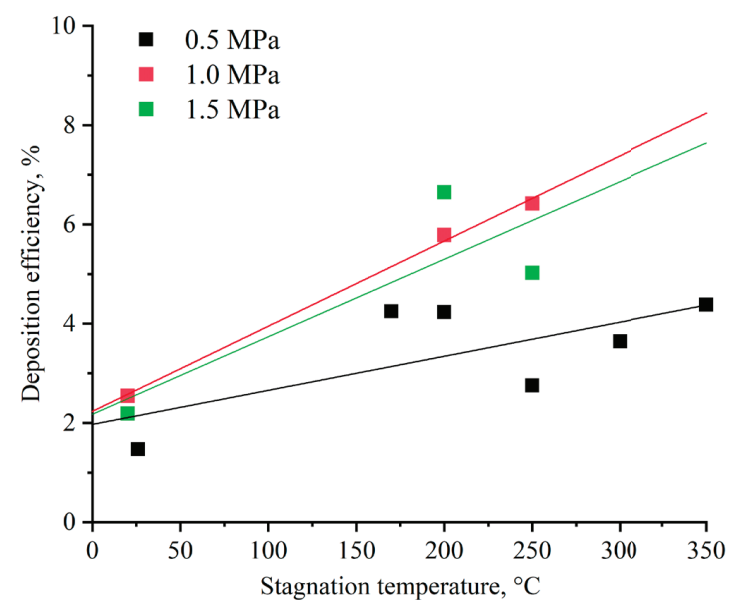

Fig. 5. Dependence of the deposition efficiency on the stagnation gas temperature at a different pressure

In Fig. 6 shows the gas flow patterns in the computational domain without particles. In this case, a wall was specified at the boundary of Inlet 1.

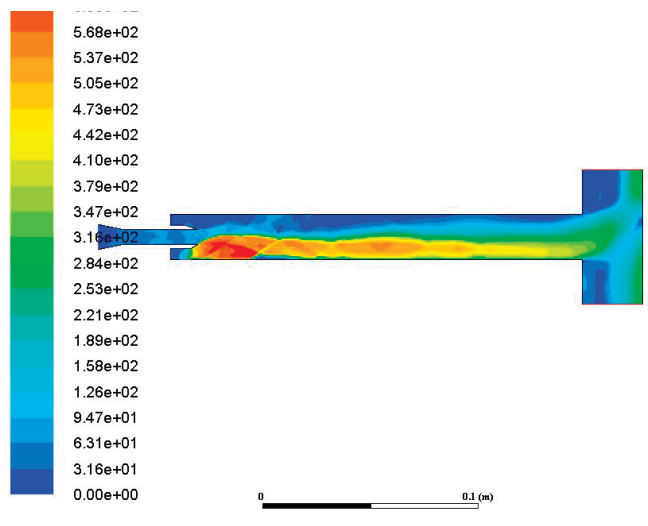

a)

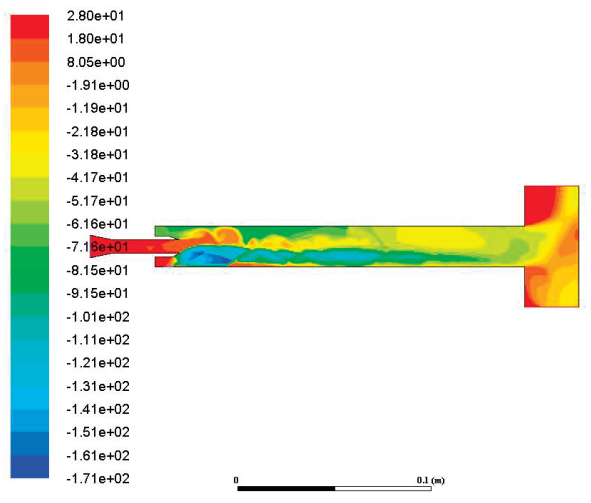

b)

Fig. 6. Gas velocity, $\mathrm{m} / \mathrm{s}(\mathrm{a})$ and temperature, ${ }^{\circ} \mathrm{C}$ (b) fields. Flow without particles, initial temperature $26{ }^{\circ} \mathrm{C}$, initial pressure $0.5 \mathrm{MPa}$

From Fig. 6a, it can be seen that the main flow moves along the lower wall of the nozzle. At the inlet boundary in the core of the flow, the gas velocity reaches $630 \mathrm{~m} / \mathrm{s}$. As it moves along the wall, the speed decreases to $400 \mathrm{~m} / \mathrm{s}$. In the expanding region near the substrate, on which the deposition takes place, the velocity is $220-250 \mathrm{~m} / \mathrm{s}$. From Fig. $6 \mathrm{~b}$, it can be seen that when leaving the Inlet 2 area, the temperature drops to $-17{ }^{\circ} \mathrm{C}$. After that, the jet is heated to a temperature of $-7^{\circ} \mathrm{C}$.

After obtaining a steady gas flow patterns in the nozzle, the particle motion was calculated. For this calculations on the Inlet 1 boundary was used next boundary conditions: the injection 
of particles normal to Inlet 1 plane, an average diameter of the particles is $0.004 \mathrm{~m}$, an initial velocity of particles is $4 \mathrm{~m} / \mathrm{s}$, and a pressure of $0.1 \mathrm{MPa}$. Fig. 7 shows the results of numerical simulation of the velocity field for a multiphase flow with particles with different initial conditions of gas phase injections.

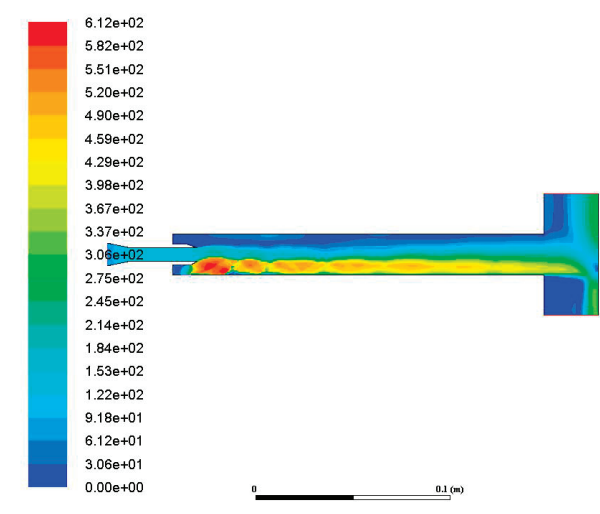

a)

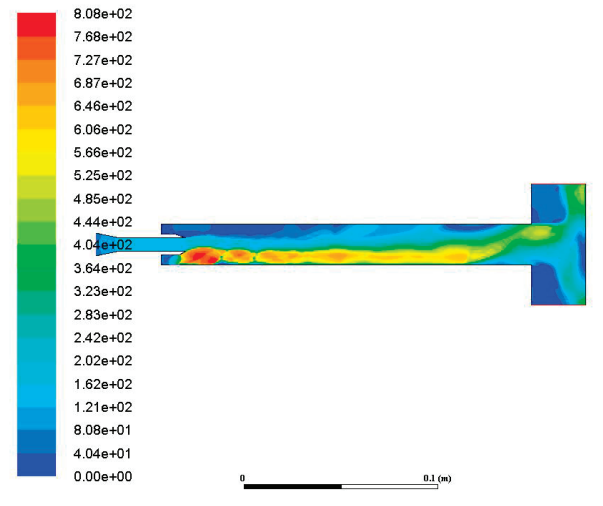

b)

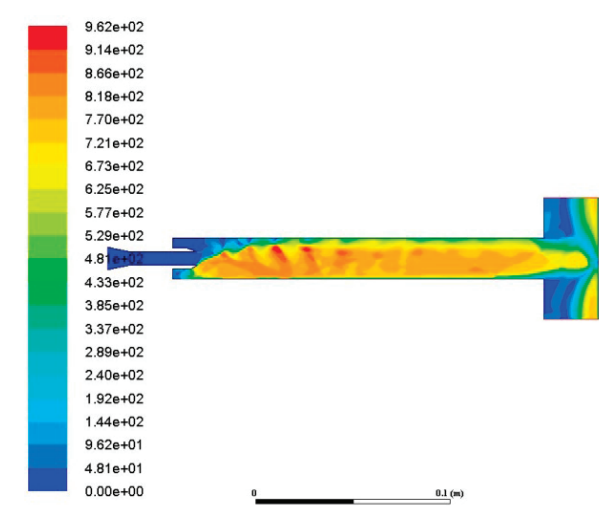

c)

Fig. 7. Results of numerical calculation of the flow velocity with particles. Gas velocity flow fields. a) $p_{0}=0.5 \mathrm{MPa}, T_{0}=26{ }^{\circ} \mathrm{C}$. b) $p_{0}=0.5 \mathrm{MPa}, T_{0}=250{ }^{\circ} \mathrm{C}$. c) $p_{0}=1.5 \mathrm{MPa}$, $T_{0}=250{ }^{\circ} \mathrm{C}$

Fig. 7a shows a change in the flow structure with an insignificant drop in the flow velocity in comparison with numerical simulation in pure gas (Fig. 6a). The gas flow is pressed against the lower wall of the nozzle. The maximum speed with which the jet approaches the substrate is 270-300 m/s. With an increase in the temperature of the working air up to $250{ }^{\circ} \mathrm{C}$ (Fig. $7 \mathrm{~b}$ ), an increase in the speed by inlet 2 up to $760-800 \mathrm{~m} / \mathrm{s}$ is noticeable. The structure of the flow along the walls of the nozzle is similar to the calculation made at $26{ }^{\circ} \mathrm{C}$ temperature (Fig. 7a); when leaving the nozzle, the structure of the flow changes the velocity at the substrate and is $300 \mathrm{~m} / \mathrm{s}$. Fig. 7c shows the velocity pulsation, which corresponds to higher parameters of the initial gas flow $\left(p_{0}=1.5 \mathrm{MPa}, T_{0}=250^{\circ} \mathrm{C}\right)$. The velocity near the substrate reaches $570-620 \mathrm{~m} / \mathrm{s}$.

The program simulates a track from the center of each cell on the injection surface. A track is the most probable trajectory of not one particle, but a whole group of particles that entered 
the computational zone through the face area of the corresponding cell. Fig. 8 shows the tracks of particles for different parameters of the gas flow.

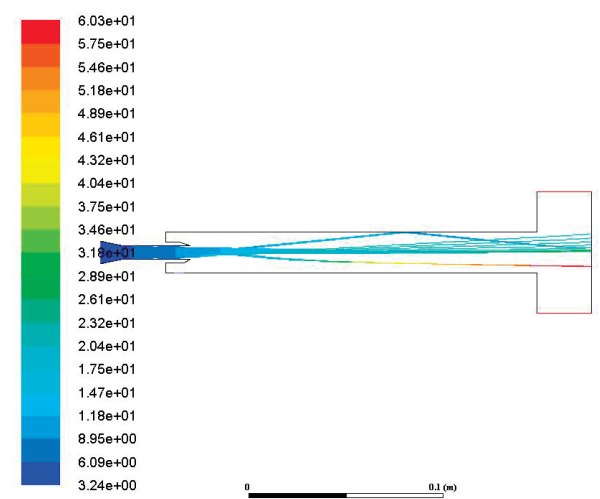

a)

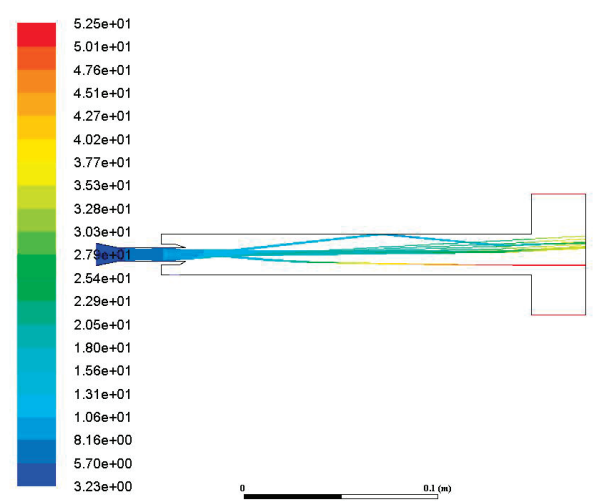

b)

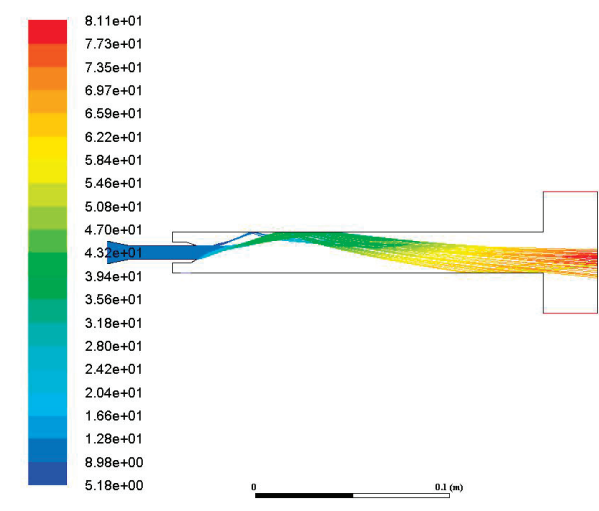

c)

Fig. 8. Particle tracks colored by particle velocity magnitude. a) $p_{0}=0.5 \mathrm{MPa}, T_{0}=26{ }^{\circ} \mathrm{C}$. b) $p_{0}=0.5 \mathrm{MPa}, T_{0}=250{ }^{\circ} \mathrm{C}$. c) $p_{0}=1.5 \mathrm{MPa}, T_{0}=250{ }^{\circ} \mathrm{C}$

Fig. 8a shows the trajectory of particles at a temperature of $26^{\circ} \mathrm{C}$ and a pressure of $0.5 \mathrm{MPa}$. The particles are accelerated by the flow and reach their maximum speed of $230 \mathrm{~m} / \mathrm{s}$ near the substrate. As the air temperature rises to $250{ }^{\circ} \mathrm{C}$ (Fig. 8b), the velocity often increases to $350 \mathrm{~m} / \mathrm{s}$, while the trajectory of the particles is similar to the calculation shown in Fig. 8a. In Fig. $8 \mathrm{c}$, at a temperature of $250{ }^{\circ} \mathrm{C}$ and a pressure of $1.5 \mathrm{MPa}$, it can be seen that the trajectory of the particles becomes wavy. The flow of particles is blown away to the upper wall of the nozzle, after which an elastic rebound occurs. In this case, the particles occupy a large area in the remainder of the nozzle after rebound. Impact with an obstacle occurs at a speed of $650-700 \mathrm{~m} / \mathrm{s}$.

\section{Conclusion}

A method of deposition thermoplastic powder to asphalt concrete by cold spray method is proposed. Experiments have shown that the deposition process is accompanied by a low 
deposition efficiency. The dependences of the deposition efficiency on the gas flow parameters are obtained experimentally. The best performance was achieved at a working gas pressure of 1.5 $\mathrm{MPa}$ and a temperature of $200{ }^{\circ} \mathrm{C}$, while the deposition efficiency was $6 \%$. Using the ANSYS Fluent software package, calculations of the motion of particles in a continuous gas medium in the Lagrangian approach have been carried out. As a result of the calculations, the values of the particle velocity during movement in the nozzle, the outflowing jet and near the substrate surface were determined from the spraying parameters (initial pressure and temperature), as well as the trajectories of the particles.

The research was supported by the Ministry of Science and Higher Education of the Russian Federation within the framework of the state assignment (project no. 121030900260-6).

\section{References}

[1] A.Papyrin, V.Kosarev, S.Klinkov, A.Alkhimov, V.Fomin, Cold Spray Technology, Elsevier Science, 2007.

[2] The Cold Spray materials deposition process. Fundamentals and applications, Woodhead Publishing Ltd, Cambridge, England, 2007.

[3] R.Maev, V.Leshchynsky, Introduction to Low Pressure Gas Dynamic Spray: Physics \& Technology, Wiley-VCH, Weinheim, 2008.

[4] A.P.Alkhimov, S.V Klinkov, V.F.Kosarev, V.M.Fomin, Cold gas-dynamic spraying. Theory and practice, Moscow: Fizmatlit, 2010 (in Russian).

[5] F.Cao, H.Park, J Heo et al., J. of Thermal Spray Technology, 22(2013), 1109-1119.

[6] W.Song, K.Jung, D.M.Chun et al., Surface Review and Letters, 17(2010), 189-193.

[7] D.Y.Kim, J.J.Park, J.G Lee et al., J. of Thermal Spray Technology, 22(2013), 1092-1102.

[8] F.Robitaille, M.Yandouzi, S.Hind et al., Surface and Coating Technology, 203(2009), 2954-2960.

[9] X.I.Zhou, A.F.Chen, J.C Liu et al., Surface and Coating Technology, 206(2011), 132-136.

[10] R.Lupoi, W.O’Neill, Surface and Coating Technology, 206(2011), 1069-1076.

[11] M. Gardon, A.Latorre, M.Torrell et al, Material Letters, 106(2013), 97-99.

[12] A.S Alhulaifi, G.A.Buck, W.J.Arbegast, J. of Thermal Spray Technology, 21(2012), 852-862.

[13] Y.Xu, I.M.Hutchings, Surface and Coating Technology, 201(2006), 3044-3050.

[14] T.A.Brusentseva, Methods of powder mixtures spraying on parts and large constructions, AIP Conference Proceedings, 2125(2019), 020015.

[15] T.Brusentseva, V.Shikalov, V.Fomin, Cold spray deposition of thermoplastic powder for road marking, EPJ Web of Conference, 221(2019), 01006.

[16] W.Y.Li, C.J.Li, H.T.Wang, C.X.Li, H.S.Bang, Measurement and numerical simulation of particle velocity in cold spraying, Journal of Thermal Spray Technology, 15(2006), 559-562. 


\title{
Моделирование процесса холодного напыления термопластичного порошка
}

\author{
Татьяна А. Брусенцева \\ Владислав С. Шикалов \\ Сергей А. Лаврук \\ Василий М. Фомин
}

Институт теоретической и прикладной механики им. Христиановича СО РАН

Новосибирск, Российская Федерация

\begin{abstract}
Аннотация. Работа посвящена нанесению композиционных порошковых материалов методом холодного газодинамического напыления (ХГН). В качестве композитного материала использовался термопластичный состав для маркировки дорожного полотна ТЕРМОПЛАСТИК «WAY». В качестве материала подложки применяли дорожное полотно с асфальтобетонным покрытием. В результате экспериментальных исследований получена зависимость коэффициента напыления от температуры рабочего воздуха в эжекторном сопле. Для оценочного моделирования процесса ХГН использовался пакет ANSYS Fluent. Получены картины течения газа в расчетной области без частиц и с учетом взаимодействия потока с частицами. Рассчитана траектория частиц при различных параметрах напыления.
\end{abstract}

Ключевые слова: холодное газодинамическое напыление, термопластичный порошок, эффективность осаждения, численный расчет, двухфазные течения, эжекторное сопло. 